\title{
Actuarial fairness in social security calculations: application of a multiple decrement model to compare the social security factor and minimum age rules
}

\author{
André Luiz Lemos Andrade Gouveia ${ }^{1}$ \\ (D) https://orcid.org/0000-0002-6976-1532 \\ Email: andre.gouveia@pmm.am.gov.br \\ Filipe Costa de Souza ${ }^{2}$ \\ (D) https://orcid.org/0000-0001-9903-5403 \\ Email: filipe.costas@ufpe.br \\ Leandro Chaves Rêgo ${ }^{3}$ \\ (D) https://orcid.org/0000-0002-4091-024X \\ Email: leandro@dema.ufc.br
}

${ }^{1}$ Manaus Previdência, Manaus, AM, Brazil

${ }^{2}$ Universidade Federal de Pernambuco, Centro de Ciências Sociais Aplicadas, Departamento de Ciências Contábeis e Atuariais, Recife, PE, Brazil

${ }^{3}$ Universidade Federal do Ceará, Centro de Ciências, Departamento de Estatística e Matemática Aplicada, Fortaleza, CE, Brazil

Received on 04.27.2017 - Desk acceptance on 06.23.2017 - $3^{\text {rd }}$ version approved on 11.27.2017 - Ahead of print on 06.28.2018

Associate Editor: Luís Eduardo Afonso

\begin{abstract}
The objective of this work was to compare the actuarially fair social security rates for the General Social Welfare Policy (GSWP), based on the social security factor rules and the minimum age proposal present in Proposed Constitutional Amendment n. 287/2016. The demographic changes that have taken place in Brazil in recent years raise questions about the sustainability of the national social security system and approving social security reform has been a government priority. Therefore, there is an undisputed need for an actuarial study that calculates actuarially fair rates and compares the current scenario with the reform proposals. Multiple decrement actuarial models were used to calculate the fair rates considering a standard family (25-year-old worker, spouse, and two children), in which the man is three years older than the woman. The IBGE 2015 Extrapolated (mortality) and Álvaro Vindas (disability) tables were adopted as biometric assumptions, and a real wage growth rate of $2 \%$ p.a. and real interest rate of $3 \%$ p.a. were used. It has been shown that under the social security factor rule current contribution rates are insufficient to cover social security benefits, since the actuarially fair rates are $30.69 \%$ and $35.27 \%$ for men and women, respectively. However, if the social security reform were approved as submitted, the fair rates would be reduced to $22.25 \%$ and $21.60 \%$, respectively. Besides the minimum age, part of this reduction is due to the proposed rules allowing pension values lower than the minimum wage.
\end{abstract}

Keywords: Social Security, RGPS, social security reform, actuarial fairness, multiple decrements. 


\section{INTRODUCTION}

On December $5^{\text {th }}, 2016$, the head of the Executive sent the Proposed Constitutional Amendment (PCA) n. 287 (Brazil, 2016) to the Chamber of Deputies, aiming to set out a new framework for social security, establish transitional rules, and make other provisions, based on the reason that such changes are needed for fiscal adjustment in Brazil. This proposed reform is based on the demographic changes that have occurred in the country in recent years and on the pressure they have exerted on the solvency of the Brazilian social security system, with the key point being the adoption of a progressive minimum retirement age (Lima \& Matias-Pereira, 2014).

Meneu, Devesa, Devesa, Dominguez, and Encinas (2016) note that introducing automatic adjustment mechanisms that can respond to changes in variables (particularly demographic ones) that affect the sustainability of social security rules has become a trend in reforms to social security systems. Also according to the authors, these automatic mechanisms are nothing more than normative instruments that regulate the value of certain parameters in accordance with variations in pre-defined indicators, with the aim of maintaining the solvency of the social security system without the need for new reforms. Two of the automatic adjustment mechanisms that stand out are the reduction factors (such as the social security factor) that alter the value of retirement benefits in accordance with variations in some demographic indicator (in particular, life expectancy) and those that associate retirement age with life expectancy (as in the case of adopting a progressive minimum retirement age).

In Brazil, according to article 194 of the 1988 Federal Constitution (FC/88) (Brazil, 1988), social security is composed of three public authority initiatives: Health, Welfare, and Pensions, whose form of funding is defined in article 195 of the FC/88. Regarding pensions, this is divided into three pillars: the General Social Welfare Policy (GSWP), for which affiliation is obligatory for Brazilian workers ruled over by the Consolidation of Labor Laws and whose pension cover is guaranteed by the federal government and operated by the National Social Security Institute (INSS), which charges employers and employees monthly contributions to guarantee this assistance; the Special Social Welfare Policy (SSWP), for which affiliation is also obligatory for public servants holding effective positions (whether with the Union, state, Federal District, or municipality); and the Complementary Pension Scheme (CPS), which is facultative and can be operated by open or closed complementary pension entities.

In light of the uncertainty caused by pension reform, workers may ask whether the contributions made in their favor over the course of their working lives - so that they have the right to pension cover - are charged in an actuarially fair way. An actuarially fair value is understood as being one for which the expected contributions are equal to the expected benefits (Afonso \& Freire, 2015; Landes, 2014). In this spirit, based on the principle of mutualism, workers would imagine themselves in a capitalization scheme and compare the expected costs needed to have the right to the possible pension benefits with the current rates charged by the State [for further discussions on the concept of actuarial fairness, see Quessier and Whitehouse (2006)].

In this context, and focusing on the GSWP, the main aim of this article is to compare actuarially fair social security rates based on the current social security factor rule and the proposed minimum retirement age [set out in the original text of PCA n. 287/2016 (Brazil, 2016)], using a multiple decrement actuarial model that, for both rules, contemplates planned retirement and retirement due to disability and their pension reversions, as well as death pensions for active employee.

At this point it is worth mentioning that: first, regarding planned retirement, for simplicity it is considered that individuals retire as soon as they are eligible; second, for modeling purposes, aspects linked to progressive rule 85/95 will not be discussed, since as time passes, given the parameters adopted in this study, individuals would primarily become eligible via the social security factor rule.

This study contributes to the literature by way of two central factors: first, the existing models in the Brazilian literature for calculating actuarially fair social security rates, such as Giambiagi and Afonso (2009), Afonso and Lima (2011), Penafieri and Afonso (2013), and Afonso and Freira (2015), are purely financial or single decrement models and therefore end up omitting benefits such as retirement due to invalidity, among others. As a result, such studies tend to underestimate the value of the fair rates. Thus, the use of multiple decrement models enables a more accurate calculation of social security rates. Second, by comparing the social security factor rule with the minimum retirement age rule, the study enables potential impacts of the reform to be ver- 
ified, thus enhancing the current debate regarding Brazilian pensions and the legislation's use of automatic adjustment mechanisms.

In order to achieve the goal set, the rest of the text is organized into five sections. Section 2 discusses the related studies and the legislation inherent to the topic.
Section 3 presents the assumptions and the models adopted to calculate the actuarially fair social security rates. Section 4 set outs the main results of the study and section 5 carries out a sensitivity analysis of the model parameters. Finally, section 6 presents the conclusions of the study.

\section{LITERATURE REVIEW}

\subsection{Related Studies}

In the Brazilian literature, the study from Giambiagi and Afonso (2009) is one of the first to calculate balanced social security rates. In this study, a financial model was developed for calculating balanced contribution percentages - that is, which equate the contribution flow to the benefit flow - for a planned retirement benefit in accordance with pension contribution period (PCP). As a main result, the authors obtained social security contribution rates in the order of $25 \%$ for men and $27 \%$ for women, which led them to the conclusion that the current percentages (between $28 \%$ and $31 \%$ ) were excessive.

In a subsequent study, Afonso and Lima (2011) revisited the financial model from Giambiagi and Afonso (2009), incorporating probabilities of death into the analysis in order to make it an actuarial model. Despite the proposed innovation, this study presented similar results to its predecessor, as well as some modeling limitations, such as the use of abbreviated mortality tables for ages higher than or equal to 80 , thus leaving room for improvements.

Penafieri and Afonso (2013) changed the focus of analysis and investigated whether the social security factor was actuarially fair based on the Giambiagi and Afonso (2009) financial model. The researchers concluded that for early retirements the social security factor would tend to reduce the retirement benefits more than necessary to equate the contribution flow to the benefits flow. In the case of delayed retirement the result was the opposite. Thus, in general, the factor was not actuarially fair. Another relevant finding of the study was the pension subsidy for women being to the detriment of men, given the benefits that they receive in the social security factor calculation.

More recently, Afonso and Freire (2015) expanded the Afonso and Lima (2011) actuarial model, improving the methodological procedures and incorporating the PCP death pension benefit. With the inclusion of this benefit in the mathematical procedures, the authors verified that for a couple with two children the fair rates surpassed $30 \%$ in most cases and that the predominant factor for the rise in this percentage was the age difference between couples.

The aforementioned articles reveal the evolution of the Brazilian studies on social security rates and actuarial fairness, also indicating a lack of research in the area. However, even with the advancements of the Giambiagi amd Afonso (2009) financial model towards the Afonso and Freire (2015) actuarial model, which also incorporates death pension benefits, the Brazilian literature still lacks multiple decrement actuarial models capable of modeling other benefits, such as retirement due to disability and death pensions for disabled people. Thus, the rates found in previous studies are underestimated since they omit the aforementioned benefits and should therefore be interpreted with due reservations.

Fontoura, Cardoso, Rocha, Capelo, and Câmara (2006) and Oliveira, Beltrão, and Maniero (1997) presented the main actuarial studies on calculating social security contribution rates in a multi-decremental environment. The former is clearly lagged and needs adjustments in the model to accompany changes in legislation, while the latter is dedicated to the SSWP and also needs updated. More recently, the study from Corrêa, Queiroz, and Ribeiro (2014) used a multiple decrement actuarial model to study how the solvency of a municipal SSWP is affected by the variability of demographic events. Despite the relevance, the central aim of this article is not to discuss fair rates. Thus, these facts only highlight the relevance of this study.

In relation to the international literature, some studies on actuarial fairness in the context of pensions can be highlighted. Ginn (2004) discusses the relationship between actuarial fairness and social fairness, with the main focus of this discussion being the traditional difference in the lifetime of men and women. Belloni and 
Maccheroni (2013) studied the transition process of the Italian social security system from a defined benefits (DB) model to a defined contributions (DC) one. According to the authors, most workers that would still have the right to retire through the DB system would receive higher benefits than the actuarially fair ones, indicating the generosity in the Italian system. However, this change in the system could lead to an excessive reduction in generosity, making the benefits lower than the actuarially fair ones.

Heiland and Yin (2014) evaluated the actuarial adjustment mechanisms for the current benefits in the American social security system for workers who retire at different full retirement ages defined by the system. The authors found that the actuarial adjustment mechanisms improved with the passing of time and that the deviations from the fair benefits were currently less than $1 \%$.

\subsection{Pensions in Brazil: the Current Scenario and PCA 287/2016}

Currently, those covered by GSWP voluntarily retire in accordance with PCP, as laid out in Constitutional Amendment n. 20/1998 (Brazil, 1998), after completing 35 years of contribution for men and 30 years for women. According to Act n. 8,213/1991 (Brazil, 1991b), the value of the monthly benefit corresponds to the simple arithmetical average of the highest contribution salaries that correspond to $80 \%$ of the whole contributive period $(M)$, counting from July 1994 , multiplied by the social security factor $(f)$, which according to Act $\mathrm{n}$. $9,876 / 1999$ (Brazil, 1999) is given by:

$$
f=\frac{T_{c} \cdot a}{E_{S}} \times\left[1+\frac{\left(A_{d}+T_{c} \cdot a\right)}{100}\right] .
$$

In its formula, the social security factor adds the following factors: age at the moment of retirement $\left(A_{d}\right)$, time of contribution up to the moment of retirement $\left(T_{c}\right)$, life expectancy on the date of retirement $\left(E_{s}\right)$, considering the biometric table for both sexes, as well as the contribution rate $(a)$, set at 0.31 .

Campos and Souza (2016) remind us that a way of inhibiting the effects of $f$ was by implementing Act. $n$. $13,183 / 2015$ (Brazil, 2013c), which refers to the progressive $85 / 95$ rule. This rule is optional and can be chosen by workers if the sum of their age at the time of retirement and the contribution period is 85 and 95 years, for women and men, respectively, as long as there is a minimum contribution period of 30 years for females and 35 for males. These values are progressive and will reach 90 and 100 years by 2026 . This progression can be seen in detail in Campos and Souza (2016).

Act n. 8.213/1991 (Brazil, 1991b) also determined the retirement benefit for disability, which is paid to people who due to accident or illness are unable to work, except in the case foreseen in article 42 of Act $n$. 8,213/1991 (Brazil, 1991b). This monthly retirement benefit corresponds to $M$.

Finally, also based on the aforementioned law, there is the death pension benefit, which will be given to the dependents of public employee in the case of their death. The value of the benefit corresponds to $100 \%$ of the value of the insured person's pension or of the benefit that they would receive if they were retired due to disability on the date of their death. Regarding the period the pension is received, it is known that the pension ceases for children at 21 years old, in accordance with line I of article 16 of Act n. 8,213/1991 (Brazil, 1991b), while the spouse receives the benefit for the time stipulated in Act n. 13.135/2015 (Brazil, 2015a), summarized in Table 1.

Table 1

Duration of the death pension benefit for spouses

\begin{tabular}{cc}
\hline $\begin{array}{c}\text { Period received } \\
\text { (years) }\end{array}$ & $\begin{array}{c}\text { Age of spouse } \\
\text { (years) }\end{array}$ \\
\hline 3 & $<21$ \\
\hline 6 & $21-26$ \\
\hline 10 & $27-29$ \\
\hline 15 & $30-40$ \\
\hline 20 & $41-43$ \\
\hline Lifelong & From 44 onwards \\
\hline
\end{tabular}

Source: Act n. 13,135/2015 (Brazil, 2015a). 
Regarding the original reform proposal, according to the $1^{\text {st }}$ article of PCA n. 287/2016 (Brazil, 2016), which among other points alters article 201 of the $\mathrm{FC} / 88$, the PCP benefit will correspond to a fixed percentage of $51 \%$ plus one percentage point for each year contributed of the simple arithmetical average of all contribution salaries $\left(M^{\prime}\right)$, with the total percentage limited to $100 \%$ and which cannot be lower than the minimum wage (MW) nor higher than the GSWP ceiling. It is thus noted that $f$ will cease to be used with the alterations proposed by PCA n. 287/2016 (Brazil, 2016). The granting of this benefit depends on a minimum contribution period of 25 years and a minimum age, for both sexes, of 65. The text of PCA n. 287/2016 (Brazil, 2016) also foresees that this age will be raised by one year whenever there is a one year increase in life expectancy at 65 years old.

It is worth remembering that for contribution purposes employers are obliged to contribute $20 \%$ of their employees' salaries on their behalf, as set out in line I of article 22 of Act n. 8,212/1991 (Brazil, 1991a), and that employees contribute in accordance with Table 2, based on Ministry of Finance Directive n. 8/2017 (Brazil, 2017), which also sets the MW and the ceiling at R $\$$ 937.00 and $\mathrm{R} \$ 5,531.31$, respectively.

Table 2

Contributions table for those insured by the National Social Security Institute (INSS) from January 1, 2017

\begin{tabular}{cc} 
Contribution wage & $\begin{array}{c}\text { Rate for tax } \text { collection purposes } \\
(\%)\end{array}$ \\
\hline up to $1,659.38$ & 8 \\
\hline from $1,659.39$ to $2,765.66$ & 9 \\
\hline from $2,765.67$ to $5,531.31$ & 11 \\
\hline
\end{tabular}

Source: MF Directive $n .8$ of January $13^{\text {th }}, 2017$ (Brazil, 2017).

The value of the benefit for retirement due to disability (permanent incapacity), when exclusively due to an accident at work, will be $100 \%$ of $M^{\prime}$, according to PCA n. 287/2016 (Brazil, 2016), respecting the pension limits.

Death pensions will undergo major modifications if PCA n. 287/2016 (Brazil, 2016) is approved. The monthly income value will correspond to a (fixed) family quota of $50 \%$ plus individual quotas of $10 \%$ per dependant, up to a limit of $100 \%$ of $M^{\prime}$. The value of the benefit could therefore be lower than one MW. The individual quotas granted will not be reversible for the other beneficiaries, and this cessation period will be defined in the terms of the act.

\section{METHODOLOGICAL PROCEDURES}

This section presents the actuarial assumptions that represent the framework needed to carry out this study, as well as the multiple decrement actuarial models for calculating the expected present value of the benefits (namely: planned retirement, death pension for an active employee, death pension for a non-working person in planned retirement, retirement due to disability, and death pension for a disabled person) and the actuarially fair social security contribution model. The models are defined based on the legal aspects discussed in section 2.2. Moreover, whenever possible, the study sought to use the standard actuarial notation (Bowers, Gerber, Hickman, Jones, \& Nesbitt, 1997).

\subsection{Actuarial Assumptions}

This subsection presents the main assumptions adopted in this study. They aim to portray the Brazilian reality and are based on previous studies, legal aspects, and try to maintain the conservative character of the analysis. In this spirit, the assumptions adopted are:

[ Family composition: in accordance with the Brazilian Institute for Geography and Statistics (IBGE, 2013) and Rodrigues and Afonso (2015), a standard family, composed of a couple (man and women) and two children (without gender distinction), is 
assumed. In addition, according to the IBGE (2015), the husband will be three years older than the wife. Finally, based on the arguments set out in Health Brazil 2014: an analysis of the state of Healthcare and of external causes (Brazil, 2015b), it is assumed that the wife will have her first child at the age of 30 years old and the second one at the age of 32 years old.

- Age of entry into the labor market: the worker, whether male or female, starts working at the age of 25 years old, with the intention of minimizing effects of the rotation assumption, which will not be addressed in this study. Therefore, as in studies such as the one from Giambiagi and Afonso (2009), among others, a contribution density of $100 \%$ is assumed; that is, there are no periods of work interruption caused by dismissals or other factors.

- Economic factors: the real interest rate will be 3\% per annum (p.a.) and the real wage growth rate will be $2 \%$ p.a., as according to Afonso and Freire (2015). To conclude the approach regarding the economic aspects, a real benefits growth rate of $0 \%$ will be adopted, which is consistent with the finding of Rocha (2015) that the readjustments to the benefits of GSWP retirees and pensioners between 2004 and 2015 did not represent the real gain.

- Demographic factors: for able and disabled person mortality, the IBGE 2015 Extrapolated table will be used (separated by sex for able people and both sexes for disabled people and children). For entry into disability, which will be seen as an irreversible event, the table chosen will be the Álvaro Vindas one.

\subsection{Actuarial Models}

As mentioned, the models developed in this study are multiple decrement, which according to Dickson, Hardy, and Waters (2013) are characterized by the existence of an initial state (common to all the individuals) and multiple exit states, with the possibility of transition from the initial moment. In addition, after the individual's exit from the initial state to some exit state, reentry into the initial state or any other state transition is not allowed. In the context of pensions, for example, these multiple decrements indicate the reasons for which a worker can leave working life, including the following: death, disability, and retirement, among others.

These factors are incorporated into the actuarial model using able people mortality rates, entry into disability etc., extracted from the respective biometric ta- bles. However, according to Winklevoss (1993), the way biometric tables are created, they only cover the respective decrement to which they refer, so that they would need adjustments to be used in multi-decremental environments. In this case, the rates (chance of the decrement occurring over the year) need to be converted into probabilities (chance of this decrement having occurred before the other decrements over the year in question). This conversion results in the construction of the service tables.

In this article, the death $(m)$ and disability $(d)$ decrements were addressed. Let $q_{x}^{\prime(m)}$ be the mortality rate for an active employee aged $x$ extracted from a mortality table and let $q_{x}^{\prime(d)}$ be the rate of entry into disability for an individual also aged $x$. So, according to Promislow (2011), assuming the traditional hypotheses of independence and uniform distribution of the decrements over the year in the single decrement model, the probabilities of death and disability for a person aged $x$ in a multi-decremental environment will be, respectively:

$$
\begin{aligned}
& q_{x}^{(m)}=q_{x}^{\prime(m)}-\frac{1}{2}\left(q_{x}^{\prime(m)} q_{x}^{\prime(d)}\right) \\
& q_{x}^{(d)}=q_{x}^{\prime(d)}-\frac{1}{2}\left(q_{x}^{\prime(m)} q_{x}^{\prime(d)}\right) .
\end{aligned}
$$

In addition, the probability of an active employee aged $x$ reaching age $x+1$ and still being in work is given by:

$$
p_{x}^{(\tau)}=\left(1-q_{x}^{\prime(m)}\right)\left(1-q_{x}^{\prime(d)}\right) .
$$

Other important elements in the construction of the models to be presented in the subsequent sections, in particular in the composition of the benefits flows, refer to the random incomes. Let $v=1 /(1+i)$, in which $i$ is the annual real interest rate of the market, so that the expected present value of a unitary whole life annuitydue, is given by:

$$
\ddot{a}_{x}=\sum_{t=0}^{\infty} v^{t} \cdot{ }_{t} p_{x}^{\prime(m)},
$$

in which ${ }_{t} p_{x}^{(m)}$ is the probability of someone aged $x$, in a single decrement environment, will survive at least age $x+t$. For incomes of a temporary nature, only adjustments in notation and to the upper limit of the summation are made. The decision was made to use annual payment instead of monthly annuities for simplicity reasons. 
The next six subsections present the actuarial models for calculating the actuarially fair rate. According to the original text of PCA n. 287/2016 (Brazil, 2016), pensions for spouses and children will cease in accordance with an act that is still to be published. Thus, since this act is not yet public knowledge, the technical procedures for pensions concerning the period for enjoying the benefits are based on the current legislation: Act $n$. 13.135/2015 (Brazil, 2015a) for spouses and Act n. 8.213/1991 (Brazil, 1991b) for children.

\subsubsection{Planned retirement.}

Based on the contribution period rules according to PCA n. 287/16 (Brazil, 2016), which composes the list of programmable benefits, $e$ is considered as the age of entry into the labor market and $r$ is the contribution period. Thus, the monthly income value for an insured person is found via the expression $\max \{\min [(0.51+$ $0.01 r) M^{\prime}, M^{\prime}$, Ceiling], $\left.M W\right\}$, in which the Ceiling is the maximum value to be paid by the GSWP and $M W$ is the minimum wage, where ${ }_{r} p_{e}^{(\tau)}$ is the probability of an active employee aged $e$ remaining in work until age $e+r$, the age at which they would retire, and $A_{p}$ is 13 times the monthly income (12 months plus the $13^{\text {th }}$ wage foreseen in line VIII of the $6^{\text {th }}$ article of the FC/88). Therefore, the present value of the future benefits (PVFB) for voluntary retirement according to the minimum age rule is:

$$
P V F B^{(r)}={ }_{r} p_{e}^{(\tau)} \cdot v^{r} \cdot A_{p} \cdot \ddot{a}_{e+r} .
$$

For the $P V F B^{(r)}$ formula, based on the social security factor rule, the difference would only be in the monthly income, which would correspond to $\max [\min (M f$, Ceiling $), M W]$.

\subsubsection{Retirement due to disability (permanent incapacity).}

This is the second case of retirement and comes about in the event of disability. It composes a list of risk benefits and, respecting the pension limits, its monthly value will be $M^{\prime}$. Therefore, the annual retirement benefit for disability, $A_{i}^{(k)}$, is 13 times $M^{\prime}$ (12 months plus the $13^{\text {th }}$ wage). In this case, the individual is eligible to receive this type of pension from the first day of working; that is, the whole life flow receipts can begin at any age between $e$ and $e+r-1$, because at age $e+r$ the participant would receive an income due to PCP. The first step for the modeling is to apply ${ }_{k} p_{e}^{(\tau)}$, the probability of an active employee aged $e$ surpassing all the decrements and reaching this same condition $k$ years later, followed by $q_{e+k}^{(d)}$, the probability of someone aged $e+k$ becoming disabled over the course of this age. This is necessary, since the person will only have the right to the benefit if he or she moves from work into disability over the course of a particular year, and this event can only take place if the individual is working at the start of that year. With this, an annual income $A_{i}^{(k)}$ should be considered and a whole life annuitydue $\ddot{a}_{e+k+1}^{i}$, whose difference in relation to $\ddot{a}_{x}$ comes from the probability to be incorporated, which will be $p_{e+k+1}^{\prime(i)}$, that is, the probability of a disabled person aged $e+k+1$ living until the next year. It is worth remembering that $A_{i}^{(k)}$ will have different values for each age, since the calculation is done based on the average of all the contribution salaries up to that point. The PVFB for retirement due to disability is:

$$
\operatorname{PVFB}^{(d)}=\sum_{k=0}^{r-1}{ }_{k} p_{e}^{(\tau)} \cdot q_{e+k}^{(d)} \cdot v^{k+1} \cdot A_{i}^{(k)} \cdot \ddot{a}_{e+k+1}^{i} \cdot 7
$$

The $\operatorname{PVFB}^{(d)}$ based on Act n. 8,213/1991 (Brazil, $1991 b)$ would change only in monthly income, which would be $M$.

\subsubsection{Death pension for a working person.}

Death pensions for active employees are another type of risk benefit. According to the current legislation, the monthly income value for this case will be what the worker would receive if they were to retire due to disability on the date of their death, $M^{\prime}$, and can be granted at any age $e$ up to the end of $e+r-1$, since at age $e+$ $r$ the worker will be retired and the death pension for an active employee will no longer apply in this context. The yearly value of this pension, which can be lower than one $M W$, is $P_{m}^{(x)}=13 \cdot M^{\prime}$. Quota ${ }^{(x)}$, in order to fulfill the proposal of PCA n. 287/2016 (Brazil, 2016) regarding pension reversion quotas. For this article, the value of the Quota $^{(x)}$ can be $60 \%, 70 \%$, or $80 \%$, depending on the family composition at the time.

Knowing that $e$ is the age of entry into the market, in accordance with Winklevoss (1993, p. 117-118) it is assumed that $u$ is the difference between the ages of the worker and the spouse. According to this logic, $y$ and $z$ are values which, added to the participant's age, represent the ages of their two children. In scenarios in which there are no children or when they turn 21 , the respective annuities will be 0 , since the pension will be ceased. 
In accordance with the alterations of Act n. 13,135/2015 (Brazil, 2015a), the annuities that characterize the flow of payments to spouses vary depending on their age. Thus, to meet these changes, an auxiliary function $\left(P U P_{e+x}^{(m)}\right)$ was implemented, represented by the maxi- mum between the spouse's and children's annuities. This approximation was adopted for simplicity to avoid the use of different random annuities over multiple lives. Therefore:

$$
P U P_{e+x}^{(m)}=\max \left[\ddot{a}_{e+x+u+1: \bar{\alpha}]} ; \ddot{a}_{e+x+y+1: \overline{21(e+x+y+1)} \mid} ; \ddot{a}_{e+x+z+1: \overline{21-(e+x+z+1)}]}\right]
$$

in which $\alpha=3$, for $e+x+u<21, \alpha=6$, for $21 \leq e+x+u \leq 26, \alpha=10$, for $27 \leq e+x+u \leq 29, \alpha=$ 15 , for $30 \leq e+x+u \leq 40$, and $\alpha=20$, for $40 \leq e+x+u \leq 43$.

For $e+x+u>43$ :

$$
P U P_{e+x}^{(m)}=\max \left[\ddot{a}_{e+x+u+1} ; \ddot{a}_{e+x+y+1: \overline{21-(e+x+y+1)} ;} ; \ddot{a}_{e+x+z+1: \overline{21-(e+x+z+1)}]}\right] .
$$

For the modeling of the problem, ${ }_{x} p_{e}^{(\tau)}$ and $q_{e+x}^{(m)}$, should be considered as the probability of someone aged $e$ surpassing all the decrements and reaching the same condition $x$ years later, and the probability of an active employee aged $e+x$ dying over the course of the year, respectively. The pension will only be paid in the case of the employee's death, and this event can only happen if the individual is working at the start of the year. After that, the financial discount factor applies, which is an auxiliary function that represents the unitary annuity due for each situation and the pension value in the respective period. Therefore, applying this idea in a succession of ages, the PVFB for death pensions for workers is:

$$
P V F B^{(m)}=\sum_{x=0}^{r-1}{ }_{x} p_{e}^{(\tau)} \cdot q_{e+x}^{(m)} \cdot v^{x+1} \cdot P U P_{e+x}^{(m)} \cdot P_{m}^{(x)} .
$$

It is worth remembering that the pension value $P_{m}^{(x)}$ will be different for each portion of the summation, since this value is defined based on the average of the remunerations from July 1994 up to the corresponding date and in the quota. It is important to stress that in accordance with the current legislation, the expression for the annual benefit would be $13 M$.

\subsubsection{Death pension for someone in planned retirement.}

In turn, death pensions for people in planned retirement can only begin to be paid at any age counting from $e+r$, since it is only from this age that dependents will have the right to this type of pension. According with the proposed pension reform, the monthly pension income corresponds to the retirement that gave origin to the pension multiplied by this quota; thus, the annual value is represented by $P_{a p}^{(s)}=13 \cdot M^{\prime} \cdot$ Quota $^{(s)}$. An auxiliary function, $P U P_{e+s}^{(a p)}$, should also be implemented, whose definition and application are similar to the case of the Death pension for a working person section. This reason also applies for defining $u, y$, and $z$. In light of this:

$$
P U P_{e+s}^{(a p)}=\max \left[\ddot{a}_{e+s+u+1: \bar{\beta}\rceil} ; \ddot{a}_{e+s+y+1: \overline{21-(e+s+y+1)} ;} \ddot{a}_{e+s+z+1: \overline{21-(e+s+z+1)}]}\right],
$$

in which $\beta=3$, for $e+s+u<21, \beta=6$, for $21 \leq e+s+u \leq 26, \beta=10$, for $27 \leq e+s+u \leq 29, \beta=$ 15 , for $30 \leq e+s+u \leq 40$, and $\beta=20$, for $40 \leq e+s+u \leq 43$.

For $e+s+u>43$ :

$$
P U P_{e+s}^{(a p)}=\max \left[\ddot{a}_{e+s+u+1} ; \ddot{a}_{e+s+y+1: \overline{21}(e+s+y+1)} ; \ddot{a}_{e+s+z+1: \overline{21-(e+s+z+1) 1}] .}\right] .
$$


The model is basically equal to that for death pensions for active employees, with the difference being that the summation begins from $r$ and goes up to the extreme age of the table, due to the type of pension and the related probability, $q_{e+s}^{\prime(m)}$, which will be that of the biometric table itself (rate), since from the date of retirement the individual will only be exposed to the death decrement. The PVFB for death pensions for people in planned retirement is:

$$
P V F B^{(a p)}=\sum_{s=r}^{\omega-e-1}{ }_{s} p_{e}^{(\tau)} \cdot q_{e+s}^{\prime(m)} \cdot v^{s+1} \cdot P U P_{e+s}^{(a p)} \cdot P_{a p}^{(s)}
$$

In reference to the current legislation, which accepts a reversion of the pension benefit for the other dependents when there is cessation for some beneficiary, the expression for the value of the annual pension, corresponding to $13 M f$, would come before the summation of $P V F B^{(a p)}$.

\subsubsection{Death pension for someone retired due to disability.}

To conclude the approaches regarding pension benefits, there is the death pension for someone retired due to disability. The recipient will get $100 \%$ of the original pension monthly, whose value is $M^{\prime}$. Therefore, the annual pension will be $P_{a i}^{(c)}=13 \cdot M^{\prime}$. Quota ${ }^{(c)}$. The auxiliary function $P U P_{e+q}^{(i)}$ is also present in the model for this benefit, whose annuities related to the children will be equal to 0 if their ages are higher than or equal to 21 years old, or if there are no children. Taking $u, y$, and $z$ as the values that when added to the participant's age, $e+q$, will represent the ages of the spouse and the two children, respectively, the value of $P U P_{e+q}^{(i)}$, in compliance with Act n. 13,135/2015 (Brazil, 2015a), will be:

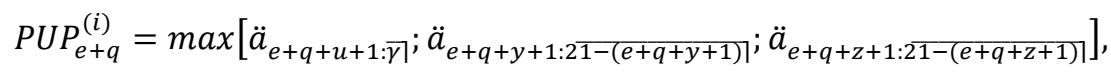

in which $\gamma=3$, for $e+q+u<21, \gamma=6$, for $21 \leq e+q+u \leq 26$; $\gamma=10$, for $27 \leq e+q+u \leq 29, \gamma=$ 15 , for $30 \leq e+q+u \leq 40$, and $\gamma=20$, for $40 \leq e+q+u \leq 43$.

For $e+q+u>43$ :

$$
P U P_{e+q}^{(i)}=\max \left[\ddot{a}_{e+q+u+1} ; \ddot{a}_{e+q+y+1: \overline{21-(e+q+y+1)} ;} \ddot{a}_{e+q+z+1: \overline{21-(e+q+z+1)}]}\right] .
$$

The expression for the PVFB for the death pension for someone retired due to disability $\left(P V F B^{(i)}\right)$ is a litthe more complex than the previous ones, since it requires two events to happen for the pension to be paid. The first step is to contemplate ${ }_{c} p_{e}^{(\tau)}$, the probability of someone aged $e$ being in the same condition $c$ years later, $q_{e+c}^{(d)}$, the probability of an individual aged $e+c$ becoming disabled over the year, and the value of the annual benefit, $P_{a i}^{(c)}$, that this occurrence will generate. If the individual is disabled, the second occurrence that should take place for the pension to start to be paid is the death of this disabled person, which is covered by $q_{e+q}^{\prime(i)}$, the probability of a disabled person aged $e+q$ dying over the year in a single decrement environment. This is only possible if the individual is alive at the start of the year, for which reason the model contains ${ }_{q-c} p_{e+c}^{\prime(i)}$. It is important to stress that $q_{e+q}^{\prime(i)}$ is an estimate derived from a single decrement environment (rate) and is therefore directly obtained from the biometric mortality table for disabled people. Finally, the modeling inserts the financial discount factor $v$ and the auxiliary function $P U P_{e+q}^{(i)}$. The PVFB for death pensions for disabled people is:

$$
P V F B^{(i)}=\sum_{c=0}^{r-1}{ }_{c} p_{e}^{(\tau)} \cdot q_{e+c}^{(d)} \cdot P_{a i}^{(c)} \cdot \sum_{q=c}^{\omega-e-1}{ }_{q-c} p_{e+c}^{\prime(i)} \cdot q_{e+q}^{\prime(i)} \cdot v^{q+1} \cdot P U P_{e+q}^{(i)}
$$


It should be highlighted that the summation that covers the chances of entry into disability only goes up to $r-1$ because from $e+r$ the individual will not, for pension purposes, be exposed to entry into disability.

Regarding the mathematical expression for $P V F B^{(i)}$, with the current legislation the monthly income value is $13 M$.

\subsubsection{Social security contribution rate.}

Social security contributions represent the offset required for individuals to have the right to the benefits mentioned in the previous sections. To describe the flow of contributions that employees and employers will make, the contribution rate should be applied to the flow of salaries, which grows annually via a real wage growth rate, and the financial discount rate. However, as this value will only be collected if the employee is alive and working, it is essential that the model contains ${ }_{t} p_{e}^{(\tau)}$, the probability of someone aged $e$ still being in work $t$ years later, in a multi-decremental environment. Consequently, the present value of the future contributions (PVFC) is:

$$
P V F C=a \cdot \sum_{t=0}^{r-1}{ }_{t} p_{e}^{(\tau)} \cdot v^{t} \cdot S_{e+t}
$$

in which $S_{e+t}$ is the annual salary at age $e+t, v$ is the financial discount factor, and $a$ is the actuarially fair rate found to equate $P V F C$ with all the $P V F B$ presented.

\section{RESULTS: THE ACTUARIALLY FAIR RATES}

The results described in Table 3 were found based on the assumptions listed in section 3.1, also considering that the employee receives one MW and that they will retire when eligible for the two cases; that is, for the current rule (social security factor rule) men retire at the age of 60 years old and women at the age of 55 years old, while for the PCA n. 287/2016 (Brazil, 2016) (minimum age) rule both retire at the age of 65 years old.

In Table 3, it can be verified that the rate derived from the current rule is above the actual one (28\%). A contribution percentage of around $31 \%$ and $35 \%$ on behalf of men and women, respectively, would be needed. It is perceived that for males planned retirement represents $59.5 \%$ of the total cost, while for females this portion is $78.2 \%$, given that the flow of benefits in the latter case begins five years before. The pension rates are higher for men, since they are calculated based on the female mortality table, which presents a higher life expectancy.

Table 3

Actuarially fair rates for the current rule and the rule from Proposed Constitutional Amendment (PCA) n. 287/2016 (Brazil, 2016) for men and women

\begin{tabular}{|c|c|c|c|c|}
\hline Benefit & $\begin{array}{c}\text { Men } \\
\text { (current rule) } \\
(\%)\end{array}$ & $\begin{array}{c}\text { Women } \\
\text { (current rule) } \\
(\%)\end{array}$ & $\begin{array}{c}\text { Men } \\
\text { (PCA rule) } \\
(\%) \\
\end{array}$ & $\begin{array}{c}\text { Women } \\
\text { (PCA rule) } \\
(\%) \\
\end{array}$ \\
\hline Planned retirement & 18.26 & 27.55 & 12.45 & 15.55 \\
\hline Pension for planned retirement & 3.32 & 2.26 & 2.44 & 1.06 \\
\hline Retirement due to disability & 2.20 & 2.52 & 2.65 & 2.72 \\
\hline Pension for retirement due to disability & 0.50 & 0.40 & 0.29 & 0.22 \\
\hline Death pension & 6.41 & 2.53 & 4.42 & 2.05 \\
\hline Total & 30.69 & 35.27 & 22.25 & 21.60 \\
\hline
\end{tabular}

Source: Elaborated by the authors. 
Given the equal percentages based on the original text of PCA n. 287/2016 (Brazil, 2016), it is noted that they were below what is currently applied. There was a reduction in these values to $22.25 \%$ for men and $21.60 \%$ for women, which means a $27.5 \%$ decrease for male workers and $38.7 \%$ for female workers, compared with the fair percentages found based on the current legislation. However, it is worth highlighting that these results would possibly rise if the illness, accident, and reclusion benefits and family and maternity wages were consid- ered in the model. Via a more detailed analysis, it can be highlighted that the retirement percentage due to disability was the only one that grew, for both sexes, compared with the contribution rates for the current rule, since the increase in planned retirement age to 65 years old also implied a longer time for the occurrence of disability. This fact extends to the death pension benefits for retirement due to disability; however, the respective contribution rates decreased due to the new rule for calculating the pension.

\section{DISCUSSION: SENSITIVITY ANALYSIS}

First, the impact of changing the mortality table for able people was analyzed, which is an assumption that causes a reduction in death rates over time. According to the IBGE, life expectancy at the age of 65 years old rose by approximately 1.5 years between 2000 and 2015; thus, in order to illustrate this growth, the IBGE 2015 Extrapolated table for both sexes was improved by $30 \%$. Improving a table consists of reducing the mortality rates and consequently increasing the life expectancies (Caldart, Motta, Caetano, \& Bonatto, 2014). This procedure involves applying a reductive percentage to the probabilities (or rates, in the multi-decremental environment) of the biometric table.

Analyzing the current legislation, according to Table 4 the fair rates will decrease compared to the standard scenario. At first, it could seem that improving the IBGE 2015 table would cause an increase in the percentages; however, this only happens for females, for a number of reasons. The contribution rates for benefits related to disability will increase, given that they are in a multi-decremental scenario; therefore, the reduction in the death rate generates an increase in the probabilities of survival. However, death pensions for active employees and those for people in planned retirement are intimately linked to the assumption in question. Thus, with the increase in $E_{S}$, employees have a greater probability of dying and their contribution rates consequently decrease, since these pension benefits are only due in the case of a worker's death. Planned retirement, in turn, is peculiar due to the presence of $f$. Improving the table causes an increase in the probability of survival and of whole life annuities. In contrast, retirement benefits will decrease, since there is the incidence of $f$, which falls with an increase in $E_{s}$. For male workers, the fall in the retirement value had a greater weight then the increases in the probabilities of survival, therefore the contribution rate for this benefit rose slightly. However, due to the considerable falls in the pension percentages, the total rate fell to $28.75 \%$. For female workers the analysis is similar. However, the incidence of $f$ did not cause a reduction in retirement benefit, since female workers would already receive one MW as a benefit in the initial situation described in section 4 . Thus, the fair percentage for planned retirement rose to $30.11 \%$, which caused a total contribution rate of $37.16 \%$.

The effects of the improvement based on PCA n. 287/2016 (Brazil, 2016) leads us to an interesting conclusion. Due to the absence of $f$, the tendency was for the total contribution rate for both sexes to rise due to the reduction in the death rate. However, improvement also resulted in an increase in the minimum retirement age, so that the fair rates were $21.17 \%$ and $20.60 \%$ for men and women, respectively; that is, there was no considerable difference compared to Table 3 . This result reinforces the need for automatic adjustment mechanisms in the legislation that respond to demographic changes, thus keeping the system stable (Meneu et al., 2016). 
Table 4

Actuarially fair rates with the mortality table for able people improved by $30 \%$ for the current rule and the rule from Proposed Constitutional Amendment (PCA) n. 287/2016 (Brazil, 2016) for men and women

\begin{tabular}{|c|c|c|c|c|}
\hline Benefit & $\begin{array}{c}\text { Men } \\
\text { (current rule) } \\
(\%)\end{array}$ & $\begin{array}{c}\text { Women } \\
\text { (current rule) } \\
(\%)\end{array}$ & $\begin{array}{c}\text { Men } \\
\text { (PCA rule) } \\
(\%)\end{array}$ & $\begin{array}{c}\text { Women } \\
\text { (PCA rule) } \\
(\%)\end{array}$ \\
\hline Planned retirement & 18.42 & 30.11 & 11.90 & 14.44 \\
\hline Pension for planned retirement & 2.79 & 2.14 & 2.20 & 1.00 \\
\hline Retirement due to disability & 2.22 & 2.54 & 3.05 & 3.12 \\
\hline Pension for retirement due to disability & 0.57 & 0.48 & 0.38 & 0.30 \\
\hline Death pension & 4.76 & 1.90 & 3.64 & 1.74 \\
\hline Total & 28.75 & 37.16 & 21.17 & 20.60 \\
\hline
\end{tabular}

Source: Elaborated by the authors.

Regarding disabled person mortality, the IBGE 2015 - Both sexes table, whose complete life expectancy at birth, $\mathrm{e}_{0}$, is 75.5 years old, was used. However, it is quite true that disabled people are exposed to a higher probability of death compared to able individuals. In an attempt to incorporate this question, the mortality tables for disabled males and females constructed by Ribeiro, Reis, and Barbosa (2010) was used, whose methodology was based on Bayesian statistical models for an urban population. The results are in Table 5 .
For the four cases, the total contribution rate falls, although by a negligible amount. It is perceived that the changes were only in the two benefits linked to the occurrence of death of a disabled person. The fair percentage for retirement due to disability was reduced due to the decrease in the flow for this benefit, given that with the changing of the table the individual became more prone to death. For this same reason, the rate for the respective pension was raised.

Table 5

Actuarially fair rates with the mortality tables for disabled males and females from Ribeiro et al. (2010)

\begin{tabular}{|c|c|c|c|c|}
\hline Benefit & $\begin{array}{c}\text { Men } \\
\text { (current rule) } \\
(\%)\end{array}$ & $\begin{array}{c}\text { Women } \\
\text { (current rule) } \\
(\%)\end{array}$ & $\begin{array}{c}\text { Men } \\
\text { (PCA rule) } \\
(\%)\end{array}$ & $\begin{array}{c}\text { Women } \\
\text { (PCA rule) } \\
(\%)\end{array}$ \\
\hline Planned retirement & 18.26 & 27.55 & 12.45 & 15.55 \\
\hline Pension for planned retirement & 3.32 & 2.26 & 2.44 & 1.06 \\
\hline Retirement due to disability & 1.54 & 2.10 & 1.87 & 2.31 \\
\hline Pension for retirement due to disability & 0.95 & 0.67 & 0.68 & 0.38 \\
\hline Death pension & 6.41 & 2.53 & 4.42 & 2.05 \\
\hline Total & 30.48 & 35.11 & 21.86 & 21.35 \\
\hline
\end{tabular}

Source: Elaborated by the authors.

To conclude the approaches from the biometric field, the assumption of entry into disability was analyzed. The first calculations considered the Álvaro Vindas table; however there is one table, from Gomes, Fígoli, and Ribeiro (2010), created based on real GSWP data, in which the probability estimates possibly represent the Brazilian scenario well.

Considering the current molds, for a male worker with a standard family and with the new actuarial assumption, Table 6 indicates an increase in the fair rate to $36.09 \%$, that is, $8.09 \%$ above that practiced by the INSS. This value is primarily due to the percentages needed for retirement due to disability and consequently its pension, which were $8.78 \%$ and $2.19 \%$, respectively. The table from Gomes et al. (2010) presents quite high estimates and this was reflected in the increase in the benefits that are linked to disability. Based on the PCA n. 287/2016 (Brazil, 2016) rules, the contribution rates behaved similarly to those for the current rule. There was an increase to $28.11 \%$ and $26.82 \%$ for men and women, respectively, with the retirement due to disability percentage standing out, which reached $10.94 \%$ for males and $11.33 \%$ for females. 
Table 6

Actuarially fair rates with the entry into disability table from Gomes et al. (2010) for the current rule and the rule from Proposed Constitutional Amendment (PEC) n. 287/2016 (Brazil, 2016) for men and women

\begin{tabular}{|c|c|c|c|c|}
\hline Benefit & $\begin{array}{c}\text { Men } \\
\text { (current rule) } \\
(\%)\end{array}$ & $\begin{array}{c}\text { Women } \\
\text { (current rule) } \\
(\%)\end{array}$ & $\begin{array}{c}\text { Men } \\
\text { (PCA rule) } \\
(\%)\end{array}$ & $\begin{array}{c}\text { Women } \\
\text { (PCA rule) } \\
(\%)\end{array}$ \\
\hline Planned retirement & 15.52 & 25.29 & 9.16 & 11.47 \\
\hline Pension for planned retirement & 3.42 & 2.31 & 2.57 & 1.12 \\
\hline Retirement due to disability & 8.78 & 10.02 & 10.94 & 11.33 \\
\hline Pension for retirement due to disability & 2.19 & 1.73 & 1.30 & 0.97 \\
\hline Death pension & 6.18 & 2.48 & 4.14 & 1.93 \\
\hline Total & 36.09 & 41.83 & 28.11 & 26.82 \\
\hline
\end{tabular}

Source: Elaborated by the authors.

In reference to the real wage growth rate that composes the list of the economic assumptions, the fair social security contribution rates were calculated for a real wage growth rate of $1 \%$ p.a. In Table 7 it is possible to see the results of this application. As expected, the reduction in the growth rate caused a reduction in the contribution rate. In both cases, for both sexes, there is actuarial unfairness, since the current rates are configured as insufficient for the current legislation and excessive for PCA n. 287/2016 (Brazil, 2016).

Table 7

Actuarially fair rates with a real wage growth rate of $1 \%$ per annum for the current rule and the rule from Proposed Constitutional Amendment (PCA) n. 287/2016 (Brazil, 2016) for men and women

\begin{tabular}{|c|c|c|c|c|}
\hline Benefit & $\begin{array}{c}\text { Men } \\
\text { (current rule) } \\
(\%)\end{array}$ & $\begin{array}{c}\text { Women } \\
\text { (current rule) } \\
(\%)\end{array}$ & $\begin{array}{c}\text { Men } \\
\text { (PCA rule) } \\
(\%) \\
\end{array}$ & $\begin{array}{c}\text { Women } \\
\text { (PCA rule) } \\
(\%) \\
\end{array}$ \\
\hline Planned retirement & 17.28 & 31.38 & 11.84 & 14.84 \\
\hline Pension for planned retirement & 3.14 & 2.58 & 2.32 & 1.02 \\
\hline Retirement due to disability & 2.26 & 2.54 & 2.75 & 2.83 \\
\hline Pension for retirement due to disability & 0.50 & 0.40 & 0.30 & 0.23 \\
\hline Death pension & 6.46 & 2.56 & 4.54 & 2.12 \\
\hline Total & 29.64 & 39.46 & 21.75 & 21.04 \\
\hline
\end{tabular}

Source: Elaborated by the authors.

The next approach addresses the question of the real interest rate. This assumption is extremely important, since besides being contained in all the models it is directly linked to the country's political-economic questions. Thus, a variation in this assumption is expected to significantly alter the results. At this point, it is worth mentioning that even for a pay-as-you-go scheme the value of the contribution rates can be calculated as if the participants belonged to a capitalization scheme, as is done in notional defined contribution pension systems. These schemes have gained space in current pension reforms around the world [more details on the topic can be seen in Belloni and Maccheroni (2013)].

Due to the instability of the economic situation in Brazil, two scenarios were addressed: one with higher returns and another with lower returns. For the first case, a real interest rate of $4 \%$ p.a. was considered, in accordance with the study from Afonso and Lima (2011), while for the second, $2 \%$ p.a. was applied, with the aim of maintaining this difference of $1 \%$ between the scenarios and the rate defined in Section 3.

Analyzing the more profitable scenario, the discount factors fell due to the rise in the real interest rate, leading to lower values in the flow of contributions and benefits, with greater significance for it. Thus, the contribution rates for the five cases were expected to decrease. This information, which is valid both for the current rule and for the PCA n. 287/2016 (Brazil, 2016) rule, can be ratified by Table 8 . For the second case, described in Table 9, the analysis is similar. The total contribution rate for the current rule was around $42 \%$ and $48 \%$ for men and women, respectively, while for the PCA n. 287/2016 (Brazil, 2016) rule the equivalent percentage was $30.96 \%$ for males and $29.29 \%$ for females. 
Table 8

Actuarially fair rates with a real interest rate of $4 \%$ per annum for the current rule and the rule from Proposed Constitutional Amendment (PCA) n. 287/2016 (Brazil, 2016) for man and women

\begin{tabular}{|c|c|c|c|c|}
\hline Benefit & $\begin{array}{c}\text { Men } \\
\text { (current rule) } \\
(\%)\end{array}$ & $\begin{array}{c}\text { Women } \\
\text { (current rule) } \\
(\%)\end{array}$ & $\begin{array}{c}\text { Men } \\
\text { (PCA rule) } \\
(\%)\end{array}$ & $\begin{array}{c}\text { Women } \\
\text { (PCA rule) } \\
(\%)\end{array}$ \\
\hline Planned retirement & 13.68 & 20.81 & 9.18 & 11.39 \\
\hline Pension for planned retirement & 1.74 & 1.19 & 1.19 & 0.54 \\
\hline Retirement due to disability & 1.82 & 2.05 & 2.16 & 2.22 \\
\hline Pension for retirement due to disability & 0.34 & 0.28 & 0.24 & 0.18 \\
\hline Death pension & 5.27 & 2.12 & 3.58 & 1.69 \\
\hline Total & 22.85 & 26.45 & 16.35 & 16.02 \\
\hline
\end{tabular}

Source: Elaborated by the authors.

Table 9

Actuarially fair rates with a real interest rate of $2 \%$ per annum for the current rule and the rule from Proposed Constitutional Amendment (PCA) n. 287/2016 (Brazil, 2016) for men and women

\begin{tabular}{|c|c|c|c|c|}
\hline Benefit & $\begin{array}{c}\text { Men } \\
\text { (current rule) } \\
(\%)\end{array}$ & $\begin{array}{c}\text { Women } \\
\text { (current rule) } \\
(\%)\end{array}$ & $\begin{array}{c}\text { Men } \\
\text { (PCA rule) } \\
(\%)\end{array}$ & $\begin{array}{c}\text { Women } \\
\text { (PCA rule) } \\
(\%)\end{array}$ \\
\hline Planned retirement & 24.37 & 36.66 & 16.81 & 21.14 \\
\hline Pension for planned retirement & 6.35 & 4.33 & 5.00 & 2.11 \\
\hline Retirement due to disability & 2.69 & 3.14 & 3.27 & 3.35 \\
\hline Pension for retirement due to disability & 0.74 & 0.58 & 0.38 & 0.28 \\
\hline Death pension & 7.90 & 3.05 & 5.50 & 2.51 \\
\hline Total & 42.04 & 47.76 & 30.96 & 29.39 \\
\hline
\end{tabular}

Source: Elaborated by the authors.

As mentioned, the approaches used previously contemplated workers who receive one MW and start their working life at the age of 25 years old. But, what would happen with the rates for a different starting salary or a different age of entry into the labor market? To answer these questions, figures 1 and 2 present the results for the total contribution rates, considering 1 to $10 \mathrm{MWs}$ and starting ages between 20 and 29, respectively.

First, note that from six minimum wages upwards, the total rate does not vary due to the existence of ceiling. In general, the increase in the starting salary results in a lower total rate, which is lower than the current rates in all cases, according to the minimum age rule foreseen in PCA n. 287/2016 (Brazil, 2016). In the current molds, men who start their working lives receiving six minimum wages or more would need $28.21 \%$ of their salary to be used as social security contributions, while for women this percentage would be $31.16 \%$.
With the proposals of PCA n. 287/2016 (Brazil, 2016), these percentages would fall to $21.30 \%$ for male workers and $20.50 \%$ for female workers.

Regarding the different ages of entry into the labor market, in most cases a decrease is perceived in the total rates with the increase in the hypothesis in question. A reduction is perceived in the percentages for planned retirement and its pension and a rise in the rates for death pensions for active employees and for retirement due to disability and its respective pension, since the planned retirement ages will also be raised, and consequently the probabilities of death for able and disabled people and of entry into disability will be lower. Specifically in the male case for the current rule, the decrease in rates related to the planned benefits was practically compensated by the increase in the percentages for the non-planned benefits, which explains the constant tendency. 


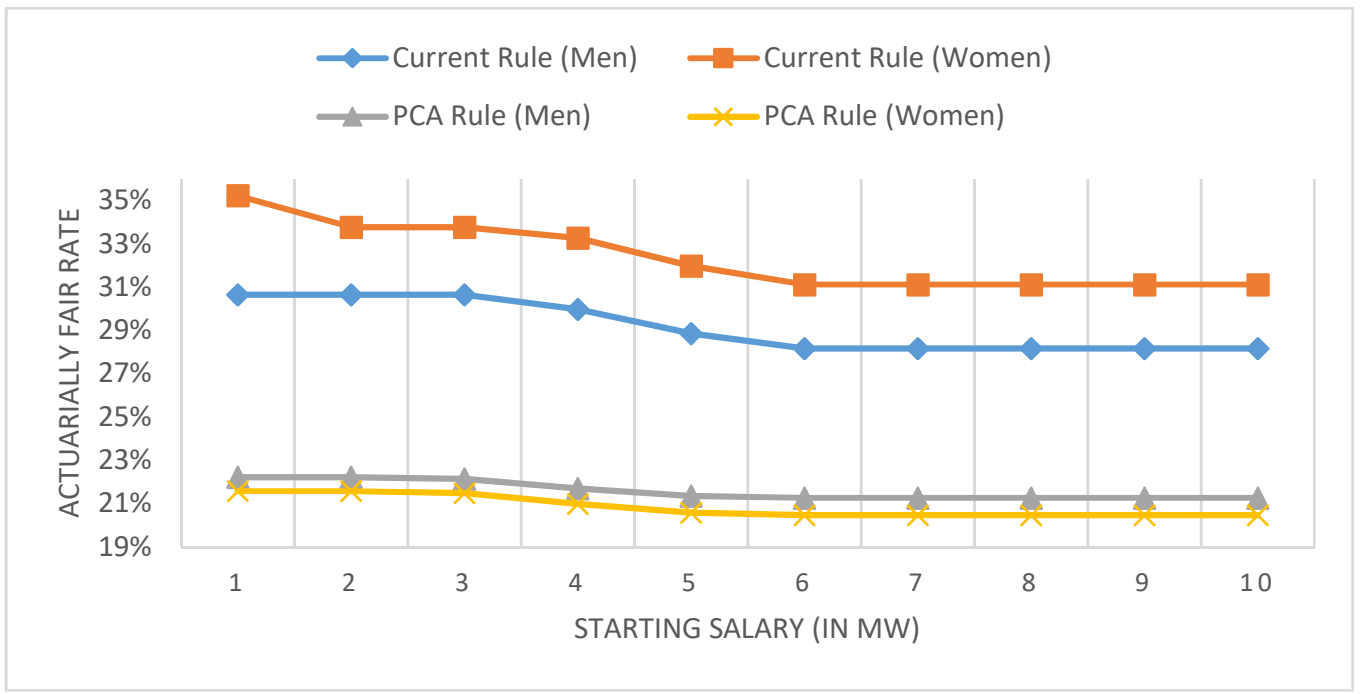

Figure 1 Actuarially fair rate for various starting salaries

PCA $=$ Proposed Constitutional Amendment n. 287/2016 (Brazil, 2016); MW = minimum wage.

Source: Elaborated by the authors.

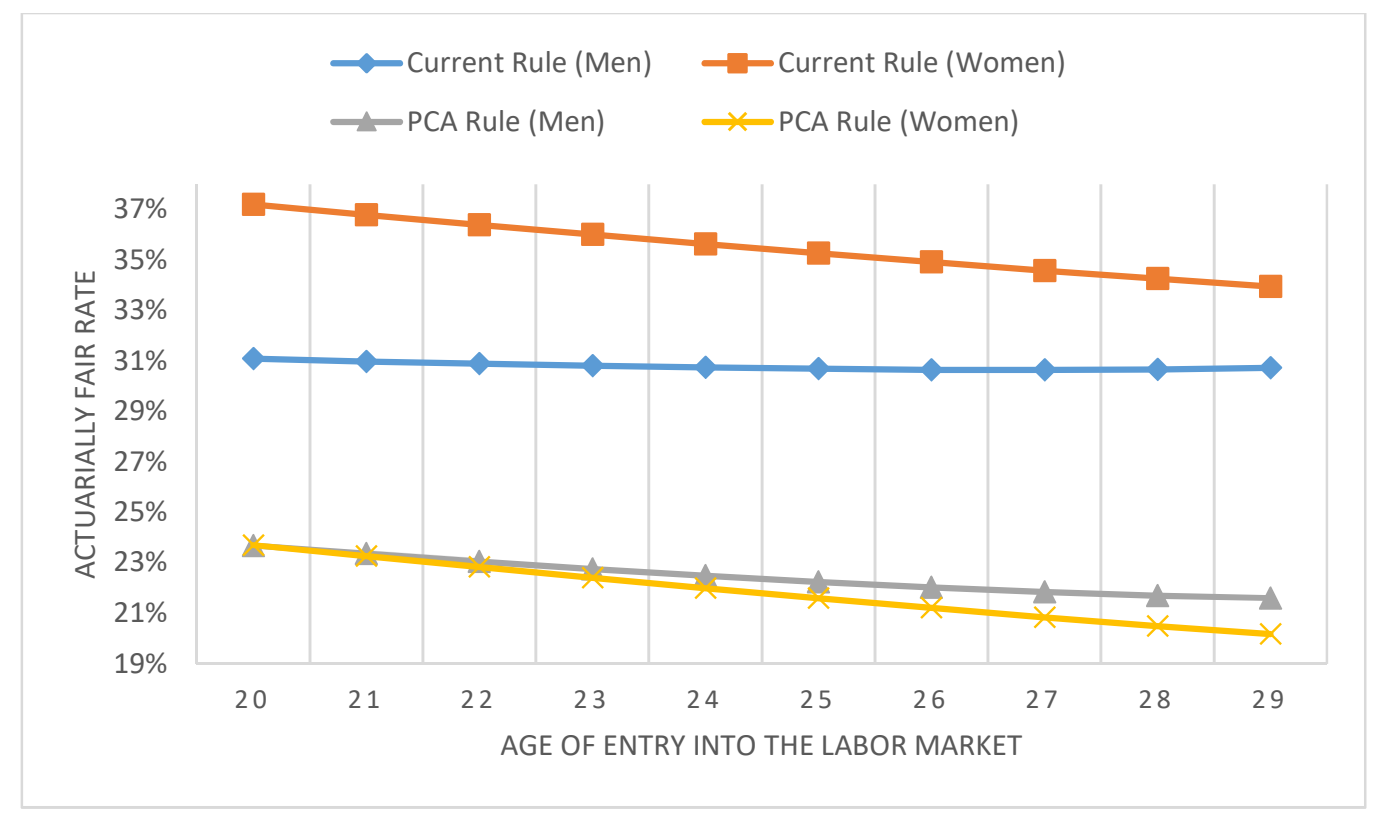

Figure 2 Actuarially fair rates for various ages of entry into the labor market

PCA $=$ Proposed Constitutional Amendment n. 287/2016 (Brazil, 2016); MW = minimum wage.

Source: Elaborated by the authors.

Finally, one point to highlight in the analyses carried out is the difference between the sexes. With the current rule, women always present higher fair rates than men; however, this is not the case when we go on to analyze the proposed pension reform. These facts indicate that the proposed changes affect women more and in some cases too much, thus heating the debate even more. 


\section{CONCLUSIONS}

The recent discussions regarding social security have not been in vain, as the relevance of this topic for the well-being of Brazilians is undeniable. The question of whether there is a surplus or deficit, one of the controversies in social security, ultimately leads to discomfort among citizens, who are concerned about the use of their pension resources, which is intimately linked to the contribution rate charged by the INSS. The aim of this study was to verify the actuarially fair percentage for the GSWP, based on the current molds and on the new parameters suggested by PCA n. 287/2016 (Brazil, 2016).

According to the assumptions initially made (especially the real interest rate), the results presented showed indications that the contributions currently collected on behalf of workers are insufficient to cover their future benefits. Since all contribution amounts are exclusively used for pensions, as according to line XI of article 167 of the $\mathrm{FC} / 88$, the missing portion to obtain actuarial fairness has to be covered by other sources. Moreover, it would be interesting for the government to make it clear to society which benefits should be effectively covered by social security contributions and which ones should be borne by other social security resources. This would make it clear what the social security rate would actually need to cover.

The results showed that for the current rule the current rates, at around $31 \%$ and $35 \%$ for men and women, respectively, fall short of what is needed. This conclusion is inconsistent with the studies from Afonso and Lima (2011) and Giambiagi and Afonso (2009), whose calculations indicated that the current contribution rate was excessive. The main reasons for the difference between the results were the inclusion of a model related to the pension benefits and the disability decrement. In relation to the study from Afonso and Freire (2015), the conclusions were similar to those of this article, due to the use of models for pensions, however with higher percentages, since they ignored the disability decrement.

Within the scope of PCA n. 287/2016 (Brazil, 2016), the primary results were inconsistent with those obtained based on Act n. 8,213/1991 (Brazil, 1991b). If the pension reform is approved as submitted, the fair social security rates would be $22.25 \%$ and $21.60 \%$ for men and women, respectively. Thus, it is perceived that the current rate would be above the fair one. Comparing the results of PCA n. 287/2016 (Brazil, 2016) with those derived from the current legislation, it is perceived that women are more adversely affected than men, since there is a difference of approximately $13.67 \%$ between the actuarially fair rates for the former, while for the latter it is $8.44 \%$. Commonly for both sexes, it is important to highlight the reduction in the percentages for the pensions that occurred due to the possibility of the benefit being lower than one MW.

To conclude, it is worth remembering that the original text of PCA n. 287/2016 (Brazil, 2016) was submitted to a special commission in Congress and at the moment some alterations have been made, notably the differentiation in the minimum age between men and women and the new method for calculating the PCP. The new proposal has not yet been voted on by the Chamber of Deputies.

\section{REFERENCES}

Afonso, L. E., \& Freire, D. R. (2015). Are the contributions rates of the Social Security General Regime (RGPS) sufficient? An actuarial study for retirement by length of contribution and survivors benefits. Revista Brasileira de Risco e Seguro, 11(19), 1-24.

Afonso, L. E., \& Lima, D. (2011). Uma análise dos aspectos distributivos da aposentadoria por tempo de contribuiçao do INSS com o emprego da matemática atuarial. Revista de Gestão e Políticas Públicas, 1(2), 7-33.

Belloni, M., \& Maccheroni, C. (2013). Actuarial fairness when longevity increases: an evaluation of Italian pension system. The Geneva Papers on Risk and Insurance - Issues and Practice, 38(4), 638-674.
Bowers, N. L., Gerber, H. U., Hickman, J. C., Jones, D. A., \& Nesbitt, C. J. (1997). Actuarial mathematics (2nd ed.). Schaumbarg, IL: Society of Actuaries.

Brasil. (1988). Constituição da República Federativa do Brasil. Retrieved from http://www.planalto.gov.br/ccivil_03/ constituicao/Constituicao.htm\#art202.

Brasil. (1991a). Lei n. 8.212 de 24 de julho de 1991. (1991, 24 de julho). Dispõe sobre a organização da seguridade social, institui plano de custeio e dá outras providências. Retrieved from http://www.planalto.gov.br/ccivil_03/leis/L8212cons.htm.

Brasil. (1991b). Lei n. 8.213 de 24 de julho de 1991. (1991, 24 de julho). Dispõe sobre os planos de benefícios da Previdência Social e dá outras providências. Retrieved from http://www.planalto.gov.br/ccivil_03/leis/L8213cons.htm. 
Brasil. (1998). Emenda Constitucional n. 20 de 15 de dezembro de 1998. (1998, 15 de dezembro). Modifica o sistema de Previdência Social, estabelece normas de transição e dá outras providências. Retrieved from http://www.planalto.gov.br/ ccivil_03/constituicao/Emendas/Emc/emc20.htm\#art1.

Brasil. (1999). Lei n. 9.876 de 26 de novembro de 1999. (1999, 26 de novembro). Dispõe sobre a contribuição previdenciária do contribuinte individual, o cálculo do benefício, altera dispositivos das Leis n. 8.212 e n. 8.213, ambas de 24 de julho de 1991, e dá outras providêcias. Retrieved from http://www.planalto.gov.br/ccivil_03/leis/L9876.htm.

Brasil. (2015a). Lei n. 13.135 de 17 de junho de 2015. (2015, 17 de junho). Altera as Leis n. 8.213, de 24 de julho de 1991, n. 10.876 de 2 de junho de 2004, n. 8.112, de 11 de dezembro de 1990, n. 10.666, de 8 de maio de 2003 e dá outra providências. Retrieved from http://www.planalto.gov.br/ccivil_03/ _ato2015-2018/2015/lei/l13135.htm.

Brasil. (2015b). Saúde Brasil 2014: uma análise da situação da Saúde e das causas externas. Brasília: Ministério da Saúde.

Brasil. (2015c). Lei n. 13.183 de 4 de novembro de 2015. (2015, 4 de novembro). Altera as Leis n. 8.212, de 24 de julho de 1991, e 8.213 , de 24 de julho de 1991, para tratar da associação do segurado especial em cooperativa de crédito rural e, ainda essa última, para atualizar o rol de dependentes, estabelecer regra de não incidência do fator previdenciário, regras de pensão por morte e de empréstimo consignado, a Lei $\mathrm{n}$. 10.779 , de 25 de novembro de 2003, para assegurar pagamento do seguro-defeso para familiar que exerça atividade de apoio à pesca, a Lei n. 12.618, de 30 de abril de 2012, para estabelecer regra de inscrição no regime de previdência complementar dos servidores públicos federais titulares de cargo efetivo, a Lei n. 10.820, de 17 de dezembro de 2003, para dispor sobre o pagamento de empréstimos realizados por participantes e assistidos com entidades fechadas e abertas de previdência complementar e a Lei n. 7.998, de 11 de janeiro de 1990; e dá outras providências. Retrieved from: http://www.planalto.gov.br/ccivil_03/ _ato2015-2018/2015/lei/l13183.htm.

Brasil. (2016). Proposta de Emenda à Constituição n. 287/2016. Retrieved from http://www.camara.gov.br/proposicoesWeb/ fichadetramitacao?idProposicao $=2119881$.

Brasil. (2017). Portaria MF n. 8 de 13 de Janeiro de 2017. (2017, 13 de janeiro). Dispõe sobre o reajuste dos beneficios pagos pelo Instituto Nacional do Seguro Social - INSS e dos demais valores constantes do Regulamento da Previdência Social RPS. Retrieved from http://normas.receita.fazenda.gov.br/ sijut2consulta/link.action?visao=anotado\&idAto $=79662$.

Caldart, P. R., Motta, S. T., Caetano, M. A., \& Bonatto, T. V. (2014). Adequação das hipóteses atuariais e modelo alternativo de capitalização para o regime básico do RPPS: o caso do Rio Grande do Sul. Revista de Contabilidade \& Finanças, 4(3), 281-293.

Campos, F. G., \& Souza, F. C. (2016). Idade ótima de aposentadoria no RGPS: uma análise sob a perspectiva de maximização dos benefícios futuros esperados. Revista de Evidenciação Contábil e Finanças, 4(3), 89-108.

Corrêa, C. S., Queiroz, B. L., \& Ribeiro, A. J. F. (2014). Tamanho populacional e custeio previdenciário: como variações aleatórias afetam o risco de solvência de RPPS municipais. Revista Eletrônica do Departamento de Ciências Contábeis \& Departamento de Atuária e Métodos Quantitativos, 1(1), 128149.

Dickson, D. C., Hardy, M. R., \& Waters, H. R. (2013). Actuarial mathematics for life contingences risks (2nd ed.). Cambridge: Crambridge University.

Fontoura, F. R., Cardoso, S., Rocha, A. S., Capelo, E., Jr. \& Câmara, S. F. (2006). Um modelo de avaliação de obrigações previdenciais de regimes capitalizados de previdência no serviço público. Revista de Contabilidade \& Finanças, 17(2), 42-55.

Giambiagi, F., \& Afonso, L. E. (2009). Cálculo da alíquota de contribuição previdenciária atuarialmente equilibrada: uma aplicaçao ao caso brasileiro. Revista Brasileira de Economia, 63(2), 153-179.

Ginn, J. (2004). Actuarial fainess or social justice? A gender perspective on redistribution in pension systems. In CeRP Fifth Annual Conference, (p. 25). Turin.

Gomes, M. M., Fígoli, M. G. B., \& Ribeiro, A. J. F. (2010). Da atividade à invalidez permanente: um estudo utilizando dados do Regime Geral De Previdência Social (RGPS) do Brasil no período de 1999-2002. Revista Brasileira de Estudos da População, 27(2), 297-316.

Heiland, F. W., \& Yin, N. (2014). Have we finally achieved actuarial fairness of social security retirement benefits and will it last? [Working Paper]. Michigan Retirement Research Center. Retrieved from http://www.mrrc.isr.umich.edu/ publications/briefs/pdf/rb307.pdf.

Instituto Brasileiro de Geografia e Estatística. (2013). Projeção da população do Brasil e das Unidades da Federação. Rio de Janeiro: IBGE.

Instituto Brasileiro de Geografia e Estatística. (2015). Estatísticas do Registro Civil (Vol. 42). Rio de Janeiro: IBGE.

Landes, X. (2014). How fair is actuarial fairness? Journal of Businesse Ethics, 123(3), 519-533.

Lima, D. V., \& Matias-Pereira, J. (2014). A dinâmica demográfica e a sustentabilidade do Regime Geral De Previdência Social. Revista de Administração Pública, 48(4), 847-868.

Meneu, R., Devesa, E., Devesa, M., Domínguez, I., \& Encinas, B. (2016). Adjustment mechanisms and intergenerational actuarial neutrality in pensions reforms. International Social Security Review, 69(1), 87-107.

Oliveira, F. E., Beltrão, K. I., \& Maniero, L. V. (1997). Alíquotas equânimes para um sistema de seguridade social (Vol. 524). Rio de Janeiro, RJ: IPEA.

Penafieri, A. C., \& Afonso, L. E. (2013). O impacto da mudança da regra de cálculo das aposentadorias por tempo de contribuição do INSS: o fator previdenciário é atuarialmente justo? Revista Economia Aplicada, 17(4), 667-694.

Promislow, S. D. (2011). Fundamentals of actuarial mathematics (2nd ed.). New Delhi: Wiley.

Quessier, M., \& Whitehouse, E. (2006). Neutral or fair? Actuarial concepts and pension-system design [Working Paper]. Organisation for Economic Co-operation and Development. Retrieved from http://www.oecd.org/els/public-pensions/ 37811399.pdf. 
Ribeiro, A. J. F., Reis, E. A., \& Barbosa, J. B. (2010). Construção de tábuas de mortalidade de inválidos por meio de modelos estatísticos bayesianos. Revista Brasileira de Estudos de População, 2(27), 317-331.

Rocha, F. R. (2015). A Previdência Social no Brasil: uma política em reestruturação. Revista Temporalis, 2(30), 453-473.
Rodrigues, D. D., \& Afonso, L. E. (2015). O impacto da criação da Funpresp sobre os benefícios previdenciários dos servidores públicos federais. Revista de Administração Pública, 49(6), 1479-1505.

Winklevoss, H. E. (1993). Pension mathematics with numerical illustrations (2nd ed.). Philadelphia, PA: University of Pennsylvania. 